\title{
The Effect of Different rearing Systems on Microscopic Quality of Fresh Semen in Thin Tail Sheep
}

\author{
Juli Mutiara Sihombing ${ }^{1}$, Emmy Kejora ${ }^{2}$ \\ ${ }^{1}$ Faculty of Agriculture and Animal Husbandry, Universitas Tjut Nyak Dhien, Indonesia \\ ${ }^{2}$ Faculty of Agriculture and Animal Husbandry, Universitas Tjut Nyak Dhien, Indonesia \\ Corresponding Author: Juli Mutiara Sihombing
}

DOI: https://doi.org/10.52403/ijrr.20220213

\begin{abstract}
The rearing system is one of the factors that determine livestock productivity. Good productivity can be influenced by the reproduction of livestock including male livestock, namely the quality of semen. Factors affecting the semen quality of thin-tailed sheep need to be considered, one of which is the livestock rearing system. This study aims to determine the microscopic quality of fresh semen of thin-tailed sheep raised with different rearing systems. The results showed that the best microscopic quality of fresh thin-tailed sheep semen was in intensive livestock rearing at parameters $80.31 \%$ motility, +++ mass movement, and $33.84 \times 108$ spermatozoa $/ \mathrm{ml}$ concentration.
\end{abstract}

Keywords: Microscopic Quality, rearing system, thin tail sheep.

\section{INTRODUCTION}

Currently, many people raise sheep, especially in the Langkat Regency. People keep sheep because sheep have several advantages compared to other ruminants such as cattle, including: (1) sheep are easy to adapt to the environment even though Indonesia is located in the tropics; (2) sheep breed quickly because within two years they can give birth three times, are prolific (more than one lamb) and seasonal polyestrous, so they can mate throughout the year (3) small capital and can be used as savings (Najmuddin and Nasich, 2019).
The sheep that are mostly kept in Langkat Regency are Thin Tailed Sheep. Thin-tailed sheep are small-bodied sheep so they are called Peanut Sheep or Javanese Sheep. Has a relatively small and thin tail, white body hair, sometimes there are other colors, for example black stripes around the eyes, nose or other parts, ewes generally do not have horns, while rams have small and coiled horns. The body weight of DET males in Jonggol aged 2-3 years is $34.90 \mathrm{~kg}$ and females is $26.11 \mathrm{~kg}$ and shoulder height is $55.66 \mathrm{~cm}$ for males and $57.87 \mathrm{~cm}$ for females (Einstiana, 2006).

The increase in the population of thin-tailed sheep really needs to be considered to increase people's income. Population increase is influenced by several factors, one of which is the livestock breeding and reproduction system. The sheep that are kept by the community there use two systems of rearing, namely the intensive and extensive system. Different rearing systems will affect the reproductive conditions of livestock including males, namely the quality of semen. In accordance with the statement of Rizal \& Herdis (2008) that several factors that affect the quality of fresh semen include the method of storage, the environment, the management used, the individual and the age of the stud used.

Based on this description, it is necessary to conduct research to determine the quality of adult male Thin-tailed Sheep 
Juli Mutiara Sihombing et.al. The effect of different rearing systems on microscopic quality of fresh semen in thin tail sheep.

semen in different rearing systems so that it can be used as a reference in the livestock rearing system.

\section{MATERIALS AND METHOD}

The research was conducted at Waringin Center Stabat Langkat. The research material used was 16 thin tailed sheep which were divided into 2 groups of 8 each. Each section received treatment, namely treatment with intensive and extensive rearing systems. Intensive rearing is carried out by keeping the cattle in cages, while extensive rearing is carried out by raising the cattle without being caged. Fresh semen was collected for each treatment and the microscopic quality was observed. The research parameters observed were motility, concentration, and mass movement. The data analysis used was a t-test for data that received $\mathrm{H} 0$ and a $\mathrm{t}$-test for the assumption of unequal variance was carried out, while for data that received $\mathrm{H} 1 \mathrm{a}$-test for the assumption of equal variance was carried out (Nuryadi et al, 2017).

\section{RESULTS AND DISCUSSION}

The results of the study of livestock semen that were treated in an intensive and extensive rearing system were tested for macroscopic quality. The microscopic quality of semen that was observed while the animals were receiving treatment were motility, mass movement and concentration.
According to Susilawati (2011) that microscopic evaluations include motility, mass movement and concentration. The research average data can be seen in Table 1.

Table 1. Average Microscopic Quality of Fresh Semen Thin Tail Sheep during the study

\begin{tabular}{|l|c|c|}
\hline \multirow{2}{*}{ Parameter } & \multicolumn{2}{|c|}{ Result } \\
\cline { 2 - 3 } & Intensive & Extensive \\
\hline Motility (\%) & $80.31 \pm 2.48$ & $71.56 \pm 2.29$ \\
\hline Mass movement & $3(+++)$ & $2(++)$ \\
\hline $\begin{array}{l}\text { Concentration } \\
\left(10^{8} \text { spermatozoa/ml }\right)\end{array}$ & $33.84 \pm 2.95$ & $30.19 \pm 2.99$ \\
\hline
\end{tabular}

From Table 1, it can be seen that the fresh semen motility of thin-tailed sheep in this study was in the range of 71.56-80.31\%. The motility of the fresh semen of the thintailed sheep was normal according to the statement of Garner and Hafez (2000) who concluded that the fresh semen of sheep had an average motility of around $60-80 \%$. From the results of the data analysis, the $\mathrm{t}-$ test hypothesis comparing the treatment of semen motility of thin-tailed sheep that were reared intensively and extensively showed significantly different results $(\mathrm{P}<0.05)$. There are differences in the motility of the semen of thin-tailed sheep that were reared intensively and extensively. The difference in motility may be due to the different processes of raising livestock even though the animals are given the same additional feed.



Figure 1. Macroscopic quality of fresh semen in different rearing systems 
The results of the graph of the quality of fresh semen showed that the macroscopic quality of intensive was better than extensive reared system. This can be seen in each research parameter.

The mass movement of the fresh semen of thin-tailed sheep in this study was at ++ and +++ . The results of the mass movement data analysis were analyzed descriptively and from the average results obtained fresh cement which has the best mass movement is in the intensive rearing system, namely +++. In accordance with Toelihere's (1993) statement, that based on the assessment of mass movement, the quality of cement can be determined by $(+++)$, visible large waves, many, dark, thick, and like black clouds approaching the time of rain.

The concentration of the results showed the range was in the range of 30.19 x $109-33.84$ x 108 spermatozoa $/ \mathrm{ml}$. The concentration values obtained in the study were within the normal range. In accordance with Toelihere's (1993) statement, the consistency or viscosity of sheep semen is thick and creamy in color and has a concentration of 2000 million to 3000 million more spermatozoa cells per $\mathrm{ml}$. Thin-tailed sheep's fresh sperm concentration from the results of the t-test Hypothesis Test data analysis showed significantly different results $(\mathrm{P}<0.05)$ between treatments. Intensively reared cows have a higher sperm concentration of 33.84 $\mathrm{x}$ 109. The high concentration of spermatozoa is influenced by many factors in one environment. In the intensive rearing system, bulls that are kept because of good rearing will affect the reproduction of the cattle to their semen characteristics such as sperm concentration. This is in accordance with the statement of Alderson (1999) that the direct influence of the environment on livestock is the level of production, feed consumption, feed rate, rearing, growth and milk production. Intensive rearing system is a rearing system with full attention and requires continuous forage supply without grazing (Mulyono and Sarwono, 2008), this system can control the influence of environmental factors that are not good and control aspects of livestock habits that are not good (Williamson and Payne 1993).

\section{CONCLUSION}

Based on the research that the microscopic quality of fresh thin-tailed sheep semen on the parameters of motility, mass movement and concentration was better in the intensive rearing system.

Acknowledgement: None

Conflict of Interest: None

\section{Source of Funding: None}

Ethical Approval: Approved

\section{REFERENCES}

1. Alderson, G.L.H. 1999. The development of a system of linear measurements to provide an assessment of type and function of beef cattle. Animal Genetic Resources Information. 25: 45-55.

2. Einstana, A. 2006. Studi Keragaman Fenotipik dan Pendugaan Jarak Genetik Antar Domba Lokal di Indonesia. Fakultas Peternakan Institut Pertanian Bogor, Bogor.

3. Garner DL, Hafez ESE. 2000. Spermatozoa and seminal plasma. In: Hafez B, Hafez ESE (eds). Reproduction in Farm Animals. 7th ed. Lippincot William and Wilkins, Philadelphia.

4. Mulyono dan Sarwono. 2008. Spesifikasi Kambing Peranakan Ettawah dalam Pemeliharaan di Lingkungan yang Berbeda. Program Penyuluh Peternakan. Dinas Peternakan Jawa Timur. Jawa Timur

5. Najmuddin.M dan Nasich.M. 2019. Produktivitas Induk Domba Ekor Tipis Di Desa Sedan Kecamatan Sedan Kabupaten Rembang. TERNAK TROPIKA Journal of Tropical Animal 
Production Vol 20, No. 1 pp. 76-83, Juni 2019.

6. Nuryadi., Astuti.T.D., Utama.S.E., Budiantara.M. 2017. Dasar-dasar Statistik Penelitian. Universitas Mercubuana. Sibuka Media Press, Yogyakarta. ISBN: 978-602-6558-04-6.

7. Rizal, M. \& Herdis (2008). Inseminasi buatan pada domba. Jakarta: Penerbit Rineka Cipta.

8. Susilawati, T. 2011. Spermatology. UB Press. Universitas Brawijaya. Malang.

9. Toelihere. 1993. Fisiologi Reproduksi Pada Ternak. Cetakan keenam. Angkasa. Bandung.
10. Williamson, G. dan W.J.A. Payne. 1993. Pengantar Peternakan di Daerah Tropis. Terjemahan: S.D. Darmadja. UGM Press. Yogyakarta. 193 p.

How to cite this article: Juli Mutiara Sihombing, Emmy Kejora. The effect of different rearing systems on microscopic quality of fresh semen in thin tail sheep. International Journal of Research and Review. 2022; 9(2): 94-97. DOI: https://doi. org/10.52403/ijrr.20220213 